\title{
MAMMOTHS, MEASURED TIME, AND MISTAKEN IDENTITIES
}

\author{
Gary Haynes
}

Anthropology Department (096), University of Nevada, Reno; Reno, Nevada 89557 USA. Email: gahaynes@unr.edu.

\begin{abstract}
Mammoth and mastodont sites containing broken or cut bones are not rare in the New World, but their meanings are ambiguous. Studies of recent African elephant bone sites indicate that certain processes in nature create bone modifications that are identical to the end-effects of human actions such as butchering. In designing a rational and efficient approach to the radiometric dating of fossil proboscidean sites, caution and skepticism should enter into interpretations of modified materials.
\end{abstract}

\section{INTRODUCTION}

Mammoth and mastodont bones figure prominently in the archeological quest to push back the earliest dates for the entry of human beings in North America. Over the past 15 years, new sites of mammoth and mastodont bones have been found that may change the chronology of the human presence in the Americas. Evidence in these sites that the extinct American proboscideans were hunted and killed by prehistoric people has taken many different forms-from the very persuasive indeed (such as undisturbed proboscidean bones interbedded with flaked-stone tools) - to the ambiguous (such as fragments of broken animal bones that lack direct association with undoubted artifacts). The most persuasive evidence imaginable would be discoveries of human skeletons, bedded directly with mammoths or mastodonts, and dated radiometrically to the same narrow time intervals. Clutched in one human hand at each site would be a spear whose stone point is stuck in an animal's rib. Nothing like this has ever been found. In general, the nature of fossil evidence about the possible interactions of mammoths, mastodonts, and people remains open to question.

Only in the last decade have we had available the body of data that will allow us to evaluate lessthan-ideal mammoth and mastodont bone sites and their possible meanings. I set a goal for this paper to reflect, for an audience of radiocarbon date users, on the issues of sample selection and interpretation of results from the proboscidean-bone discoveries. In this paper, I refer to some claims for an early human presence based on proboscidean bone discoveries, and discuss weaknesses in the reasoning behind the claims. Arguments have been advanced by some prehistorians that certain kinds of proboscidean-bone breakage or surface markings discovered in early sites are the result of human actions only, or that proboscidean deaths in specific locales and at particular times of the year surely must have resulted from human predation. These lines of argument may be too simplistic, or in fact contradict empirically verifiable patterns recorded in actualistic studies. While some recently discovered mammoth and mastodont sites may tell us important facts about the time period when the human presence was established in the New World, many more do not.

\section{Why the Measurement of Time is So Important}

We know with near certainty that humans had not colonized the Americas until long after Africa, Asia, and Europe were occupied. But because the very first moments of New World colonization are unknown, an archeological search for the timing of the earliest peopling events has driven research for over a century. The last 35 millennia of the Pleistocene-the interval of time when the first human colonists probably arrived in North America-was environmentally topsy-turvy, with abrupt and severe reversals of climate. Cold and dry periods followed upon warmer and wetter ones, sometimes cyclically and sometimes intermittently. Human dispersal into the New World would have been very different during the separate intervals of distinct climates. To understand the peopling process, and to explain its patterns and processes, we also must understand the paleoenvironmental con- 
ditions that existed at the time of the initial colonization. Hence, knowing the time when mammoth and mastodont bone sites were created will make a huge difference in trying to explain patterns of proboscidean death and possible human utilization of mammoths and mastodonts.

There's a second reason why Time is important in the debate about mammoth and mastodont bones. The topic of Time has not only intellectual meaning, but also an emotional value to North American archeologists. For generations, archeologists have argued over the earliest peopling of the New World, and firm points of view_often unshakable — are in place among members of the archeological community. Certain time intervals during the late Pleistocene are warmly favored or hotly rejected as the probable earliest colonization window. Before 1997, the advocates of very early time periods may have been in the minority, to judge from the literature, while advocates of a terminal Pleistocene date were the acknowledged standard-bearers. Clovis or fluted-point makers were generally accepted as North America's baseline culture throughout most of the continent, judging from influential sources in the mainstream literature (Meltzer 1993; Fagan 1995), until a number of archeologists (see Meltzer et al. 1997) conceded very publicly (and oracularly) that one level in the site of Monte Verde in South America in fact predates Clovis occupations thousands of miles to the north. An implication of the acceptance of the early dating is that North America must have had preClovis colonizers (or travel-through visitors) who dispersed into South America early enough to provide the Monte Verde population.

\section{Materials: A Sampling of Sites and Assemblages}

Hundreds of mammoth and mastodont sites are known in the United States, although only a small proportion have ever been well studied and reported. The sample referred to in this paper is not necessarily representative of the full range of variability to be seen in proboscidean fossil sites dating to the last 35 millennia of the Pleistocene. Table 1 shows some sites that contain ambiguous evidence about possible human interactions with mammoths or mastodonts. The table includes the sites' dates, the nature of the evidence, and literature references. I have not chosen many sites to discuss, simply because in the archeological quest to establish earlier and earlier dates for the peopling of the Americas, even single sites with pre-Clovis dates are critically important. I will not discuss each site individually, but instead I will consider the nature of the evidence in general categories, which are: butcher marks, flaked bones, stacked bones, bones with use-wear, and season-of-death patterns.

\section{Philosophy and Approach: Interpretations, 'Facts', and Measured Time}

Bone sites are sources of data, but data are not meaningful until theory and arguments are provided to make them contribute to "facts". In the system of courtroom law that we use in North America, "facts" do not exist until firm and acceptable evidence can be presented to support necessary arguments for their existence. In order for a disputed case to be won in a court of law, arguments must be made about the factual meaning of data, and the arguments must be supported by the evidence available for scrutiny. This is a healthy way of looking at archeological data and meaning, and a good example of critical thinking. In the following section of this paper, I reassess some arguments and assertions about mammoth and mastodont site data, and argue that the facts and interpretations of early sites are open to more questioning.

\section{'Butcher Marks'}

The Pleasant Lake mastodont and others found in Michigan (Fisher 1984, 1987, 1996) that died in the fall are argued to show patterned modifications to bones-such as butcher marking and burning-that reflect human actions. The sites lack clear artifactual association with the bones, and 
Table 1 Fossil proboscidean sites in the Americas that contain broken bones or marked bones interpreted as culturally modified. The sites are arranged chronologically, starting from the earliest at the top. Dates given are either based on estimates, or are midpoints in reported radiometric ranges. References are below.

\begin{tabular}{|c|c|c|c|}
\hline $\begin{array}{l}\text { Site } \\
\text { (references) }\end{array}$ & Taxon & $\begin{array}{l}\text { Date } \\
\text { (estimate or midpoint) }\end{array}$ & Evidence \\
\hline Old Crow, Yukon $(1,2,3)$ & Mammoth & $290,000-13,000$ & Flaked bones \\
\hline Miami, MO $(4,5)$ & Mastodont & $\begin{array}{l}35,900 ; 35,773 ; 41,700 \\
(\mathrm{TL})\end{array}$ & $\begin{array}{l}\text { Piled ribs; boiled bone scraps; } \\
\text { cut tusks }\end{array}$ \\
\hline Grundel, MO (6) & Mastodont & $\begin{array}{l}25,100 \\
\text { (large sigma errors) }\end{array}$ & Broken bones \\
\hline Cooperton, OK (7) & Mammoth & $20,400-17,575$ & $\begin{array}{l}\text { Broken bones; transported } \\
\text { boulders }\end{array}$ \\
\hline Inglewood, MD (8) & Mammoth & 20,070 & Broken bones \\
\hline La Sena, NE (9) & Mammoth & 18,000 & Flaked bones \\
\hline Selby and Dutton, CO (10) & Mammoth & $16,000-12,000$ & Flaked bones; 7 tiny lithic flakes \\
\hline Fenske, WI $(11,12)$ & Mammoth & 13,470 & Butcher marks \\
\hline Mud Lake, WI $(11,12)$ & Mammoth & 13,440 & Butcher marks \\
\hline Lamb Spring, CO $(8,13-16)$ & Mammoth & $13,000-11,000$ & Flaked bones \\
\hline Pleasant Lake, MI (17-19) & Mastodont & 12,$845 ; 10,395$ & $\begin{array}{l}\text { Butcher marks; cut \& burned } \\
\text { bones; bone tools }\end{array}$ \\
\hline Owl Cave, ID $(20,21)$ & Mammoth & $12,800-10,920$ & Flaked bones \\
\hline Monte Verde, Chile (22) & Mastodont & 12,500 & $\begin{array}{l}\text { Flaked bones; bone tools; burned } \\
\text { bones }\end{array}$ \\
\hline Hebior, WI $(11,12)$ & Mammoth & 12,$480 ; 12,250$ & Lithics; butcher marks \\
\hline Duewall-Newberry, TX (23) & Mammoth & $12,000-10,000$ & Flaked bones \\
\hline Burning Tree, MI (17-19) & Mastodont & $\begin{array}{l}11,660 ; 11,450 \\
\text { (gut contents?) }\end{array}$ & Butcher marks; cached bones? \\
\hline Lange-Ferguson, SD (24) & Mammoth & 11,140 & Flaked bones \\
\hline Lubbock Lake, TX (25) & Mammoth & 11,100 & Butcher marks \\
\hline Hiscock, NY (26-29) & Mastodont & $10,945-9150$ & $\begin{array}{l}\text { Lithics; bead; } 4 \% \text { of bones are } \\
\text { tools? }\end{array}$ \\
\hline \multicolumn{4}{|c|}{$\begin{array}{l}\text { 1. Irving et al. (1989); 2. Morlan (1980); 3. Morlan (1986); 4. Dunnell and Hamilton (1995); 5. Hamilton (1996); 6. Mehl } \\
\text { (1967); 7. Anderson (1975); 8. Haynes (1991); 9. Hall (1997); 10. Stanford (1979); 11. Overstreet and Stafford (1997); } 12 . \\
\text { Overstreet et al. (1993); 13. Mandryk (1998); 14. Mandryk (1999); 15. Stanford et al. (1981b); 16. Rancier et al. (1982); } \\
\text { 17. Fisher (1984); 18. Fisher (1987); 19. Fisher (1996); 20. Miller (1989); 21. Miller and Dort (1978); 22. Dillehay (1997); } \\
\text { 23. Steele and Carlson (1989); 24. Hannus (1990); 25. Johnson (1987); 26. Laub (1990); 27. Laub (1995); 28. Laub and } \\
\text { Haynes (1998); 29. Tomenchuk and Laub (1995). }\end{array}$} \\
\hline
\end{tabular}

therefore must be evaluated carefully to decide if they do contain evidence about early cultures in the New World. The butcher marks are scrapes and incisions on articular surfaces, including in some cases on "con-articular" surfaces, or, that is, on the adjoining surfaces of articulating elements. To stimulate more debate, I propose that these marks may not have been made by prehistoric people using wedges or pry-tools to separate mastodont body parts during a butchering event. The alternative agents that may have produced the marks are to be found in nature. In the same way that the original reports presented a series of assertions that the marks were made by humans during the butchering of the mastodont carcasses, I present arguments that the sequence of butchering envisioned — and that are suggested to have produced the marks—is very unlikely:

1. Some marks documented on the mastodont bone articular surfaces were made by relatively small applicators such as pointed sticks, bones, or thin poles, any one of which would certainly have broken before succeeding in separating the heavy mastodont limb parts; 
2. As well, the application of leverage with such small and thin tools inserted between articulating limb bones, as proposed, would have left impressions only on the thick cartilaginous layer that covers the articulating ends, and these impressions would have disappeared when the cartilage decayed away (see Haynes 1991, and Frison and Todd 1986 for discussion of the thickness of proboscidean cartilage on limb articulations);

3. And therefore, the marks on the bones are not large enough, deep enough, or extensive enough to have resulted from the application of the very strong leverage that would have been necessary to separate limb bones and body parts of such a heavy beast as the mastodont. The marks on the fossil bones were more likely made after the cartilage was gone, and were not made by tools that could have effectively separated meat-bearing elements. The bones from the sites about which information is available apparently were preserved in excellent condition in waterlogged or anaerobic sediments, which means that post depositional modifications to bone surfaces would not necessarily be distinct from predepositional modifications. The modifications may have occurred while bones were still buried. As an example, I refer to the 20,000-yr-old Inglewood mammoth site in Maryland, where bones with green-bone fractures and flaked cortical surfaces were modified by heavy equipment distorting the bones while they were still buried. The heavy equipment caused green-bone fragmentation to occur within the embedding sediment, and also produced bone-surface gouges and incisions, as a result of bone movement against sediment particles, shells, and other bones in the matrix.

Marks that have been interpreted by some prehistorians as wedging and butchering traces left on well-preserved fossil mastodont bones in fact may result not only from butchering, but also from noncultural post depositional processes.

Other kinds of possible butcher marks are chops and gouges (see, for example, Figure 1, a view of some marks on the Mud Lake mammoth's bones), but marks such as these are not unknown in purely natural bone accumulations, and also may result from excavation practices (probing, digging with sharp tools, etc.). Thus, they need not always be the result of human butchering actions.

\section{Broken and Flaked Bones}

A rising number of mammoth and mastodont sites described in the archeological literature yield flaked and broken limb bone fragments. The breakage and flaking appear to have been done when the bones were in a fresh condition, and the interpretations of the specimens tend to judge them either as tools created by people planning to use them in the butchering process, or as preforms and preparatory stages in the reduction process of bone fabricates. Specimens described as flaked often show features that appear to be percussion bulbs, hackle lines, and ripple marks, as well as striking platforms and feather terminations, which are the same features that flaked-stone specimens possess (see Cotterell and Kamminga 1990). The argument made about the evidence is that because the bone specimens have characteristics that are the same as seen on humanly flaked stone, they too must have been flaked by human beings when the bones were fresh (Stanford, et al. 1981a).

However, one can make another argument about the evidence. First, I concede that weathered bones do not flake in the same way as fresh bones, and I must rationally accept that the flaked bones were in a "fresh" state when modified. But what can be questioned is the time when the flaking was done. As stated above, and as is apparent to many paleontologists and archeologists who excavate ancient bones in certain sedimentary contexts, Quaternary mammalian bones are preserved extremely well sometimes, and when struck, bent, or flaked, they may behave as if "fresh" even millennia after the death of the animal. Whenever heavy equipment-such as bulldozers, dragline engines, tractors, and so forth-pass over sediments, especially wet sediments or peaty deposits enclosing bones, the 


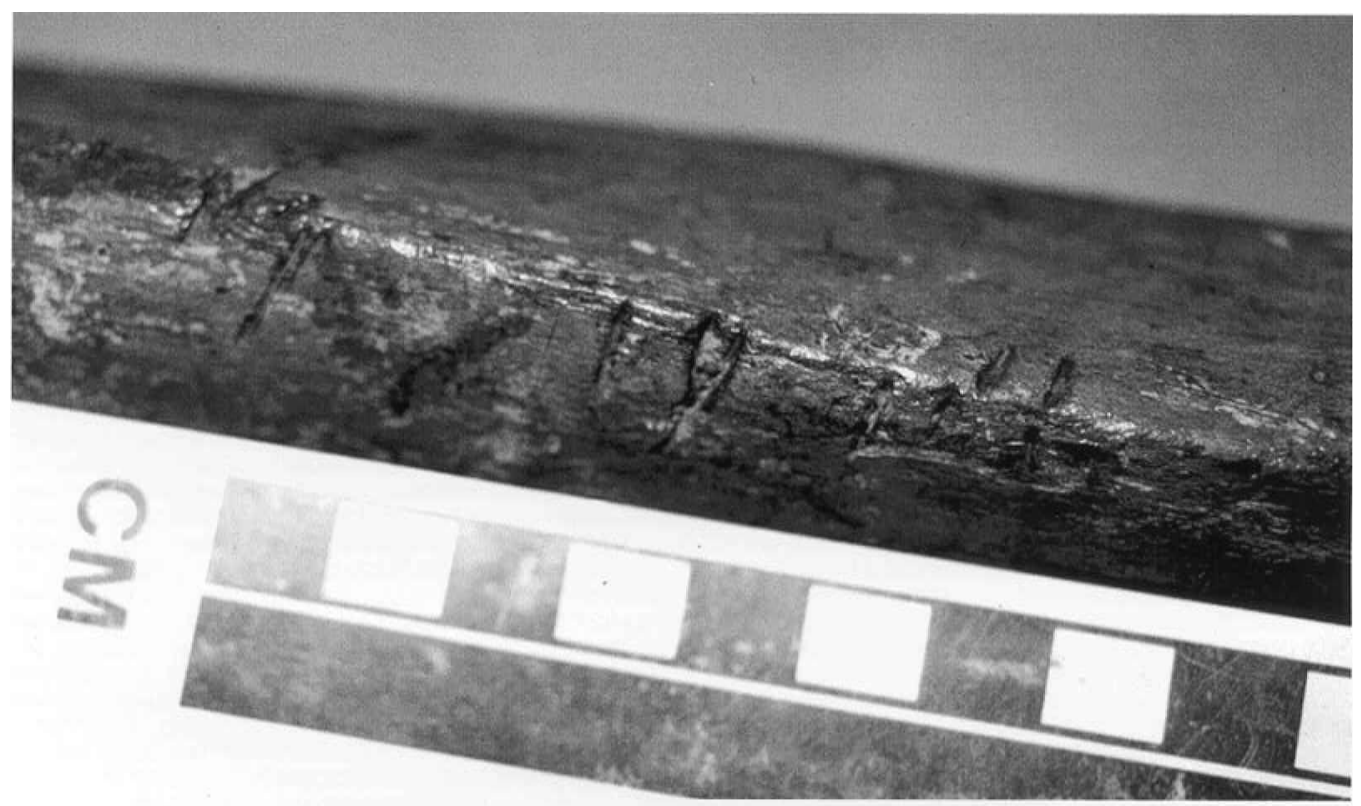

Figure 1 A bone from the Mud Lake mammoth, Wisconsin USA. These sorts of marks have been interpreted as cuts or chops made during butchering by humans (Overstreet et al. 1993). Photographed by G Haynes at the Milwaukee Public Museum.

bones and the sediments are deformed, sometimes severely. Subsurface probing, repeated surface scraping by heavy equipment, and repeated sediment block movements would bend, deform, and fracture bones embedded in the sediment. Bones and tusks bent too far will break apart in chunks, flakes, and spalls (Figure 2), some of which may appear to be percussion-flaked, because they possess features such as one thick end (appearing to be a striking platform) and one thin end (feather termination), hackle lines on ventral surfaces, ripple marks, and ring-cracking or depression fracturing where solid pressure was applied, either directly, such as when parts of the equipment contacted the bone surfaces, or indirectly, such as when the force of the equipment was applied through intermediate bodies such as other bones, pebbles, fragments of bones, or other clasts in the sediment.

Figure 3 shows a collection of fragments of elephant tusks that were broken by bending failure; these specimens were all broken by elephants pushing, shoving, and fighting with their tusks. The specimens were collected from around four water holes, and accumulated over a 3-month period during a serious drought in Zimbabwe. Many of these fragments (especially on the photograph's right) look like flakes themselves, and have hackle lines, ripple marks, bulbs of "percussion", and other features thought to be exclusively diagnostic of percussion fracturing. Well-preserved fossil tusks and bones also would show these same features when subjected to bending failure.

Figure 4 shows a specimen collected in Zimbabwe during studies of noncultural bone-modifying processes. The specimen - an elephant femur-has been spirally fractured by elephant trampling. The fracturing of this specimen is of the sort that might be mistakenly interpreted as the result of human actions, such as percussion fracturing of large limb elements. In fact, this type of modification and the end-effects of bending-failure shown in Figure 2 occur frequently in nature.

Of course, these arguments about the evidence in no way prove that humans did not break the fossil mammoth and mastodont specimens. It may be that these alternate propositions will be impugned 


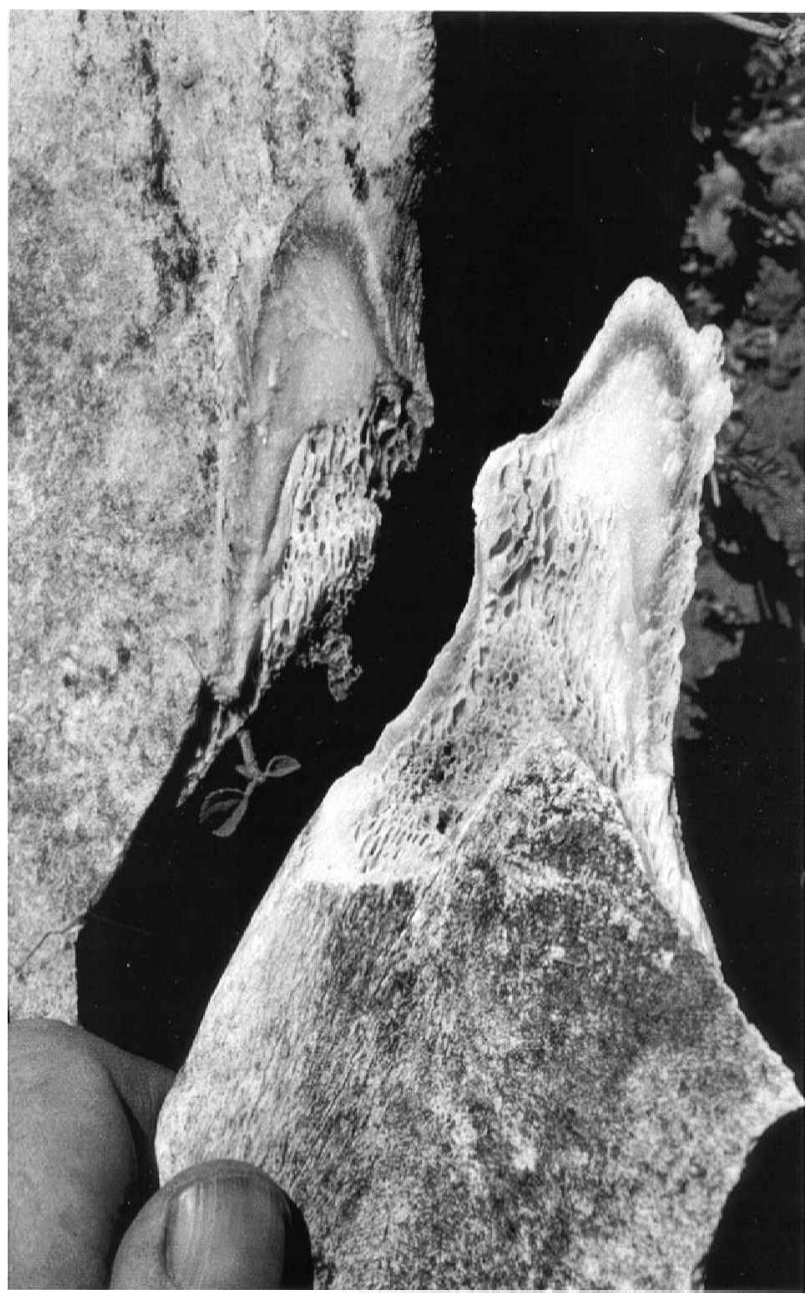

Figure 2 An example of a flake-scar created by bending-failure of a bone, rather than by percussion or pressure flaking. Photographed in Zimbabwe by G Haynes.

during a new round of argumentation. But if these arguments are accepted, they succeed in producing a reasonable doubt that fossil bones which may appear to have been percussion-flaked need not have been broken by cultural processes.

\section{'Stacked' Bones, 'Cached' Bones}

Some sites contain excavated bone concentrations that have been interpreted as deliberately stacked or piled specimens (for example, the Miami mastodont site or the Pleasant Lake mastodont). I do not understand why noncultural processes are not thought capable of concentrating bones-I have seen numerous examples of ribs heaped together in natural accumulations, or of unmatched bone elements ending up together as a result of multiple events such as elephants or scavengers carrying the elements, fluvial transport, and colluvial processes. Natural processes may preferentially sort certain elements by shape or size or mass, but they also may affect very differently shaped (and differently 


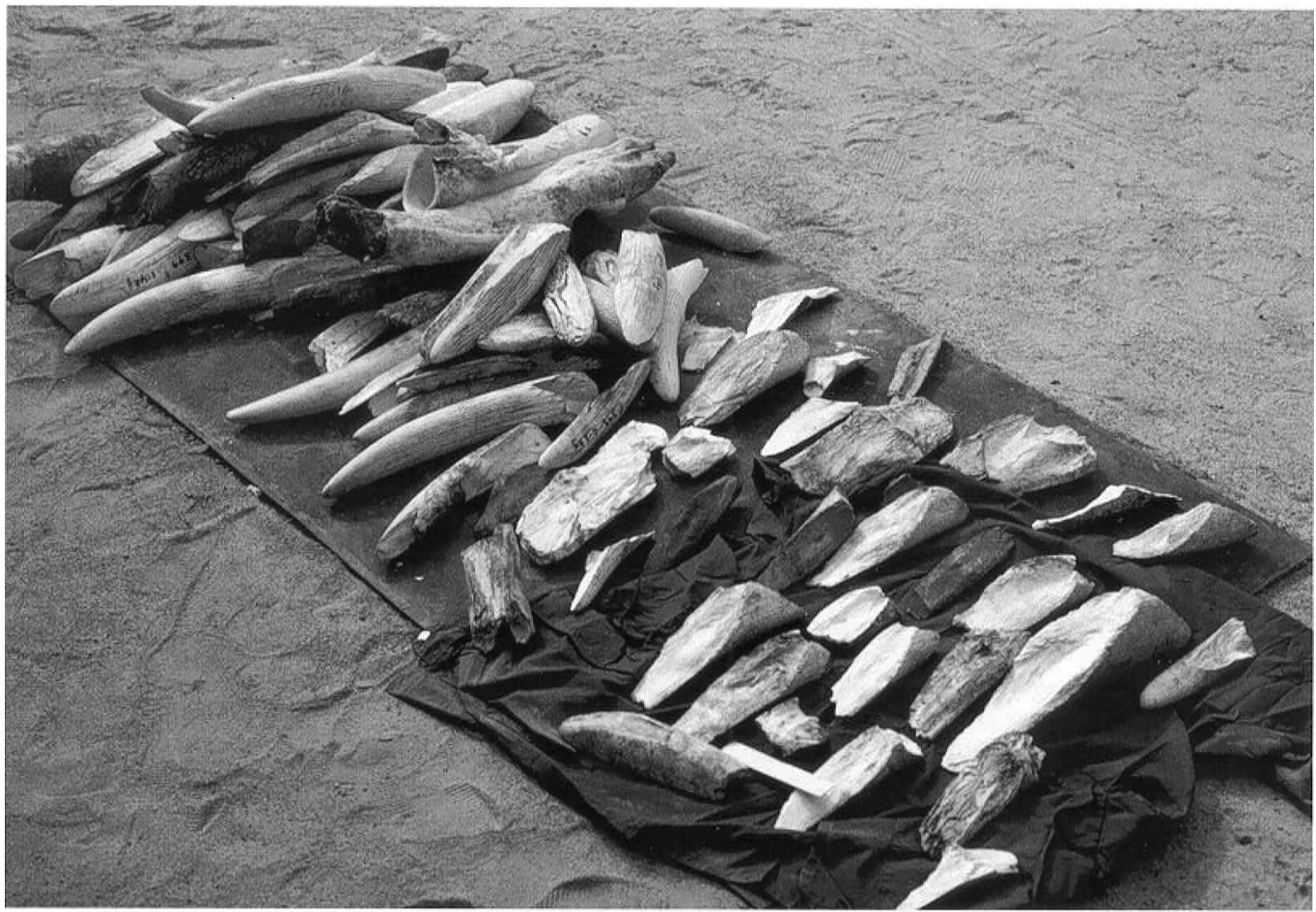

Figure 3 Tusk fragments collected from water sources in Hwange National Park. All were fractured by elephants using their tusks to shove each other away from water. Many specimens display features identical to percussion-flaked stone cores and flakes, such as bulbs, ripple marks, and hackle lines. Photographed in Zimbabwe by G Haynes.

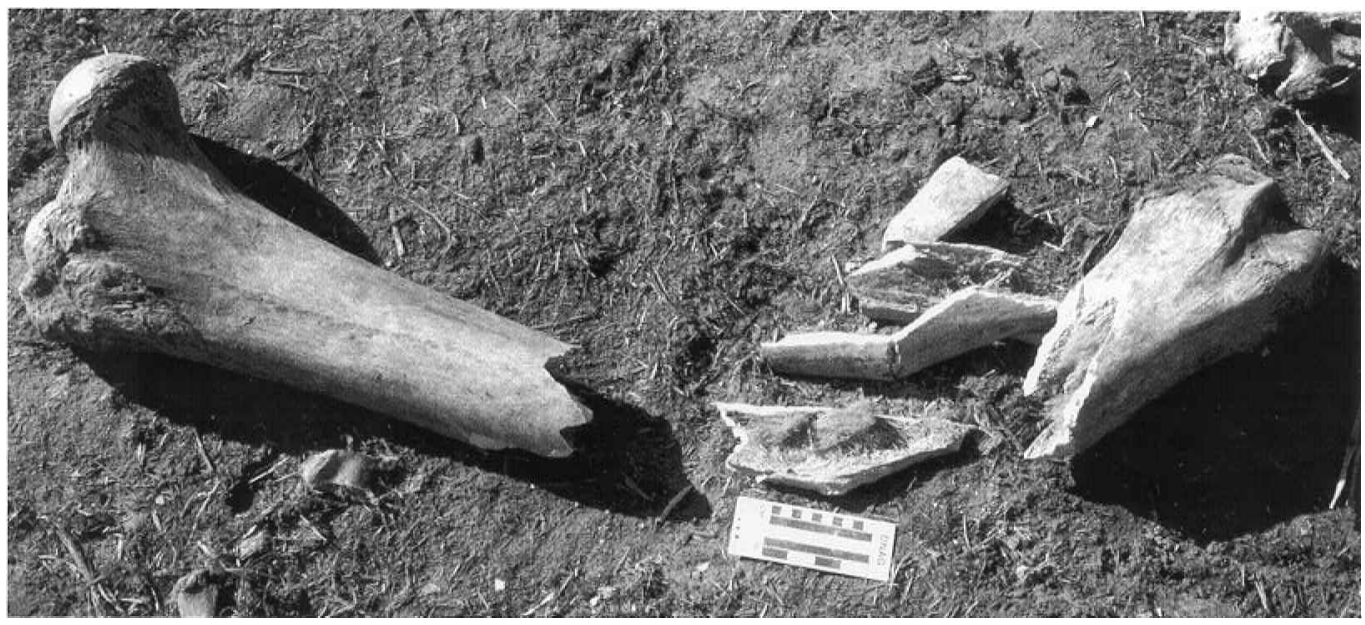

Figure 4 An elephant femur spirally fractured by elephant-trampling around a water hole in Hwange National Park, Zimbabwe. The DNAG scale bar is marked in inches at the bottom and centimeters at the top. Photographed in Zimbabwe by G Haynes. 
sized) elements in similar ways. Scavengers may drag lighter elements away to gnaw, but scavengers also may drag away heavy limb bones. Fluvial activity in one flood event may carry only small and lightweight bones, but in another flood event on another day relatively heavy bones may be affected. Certain elephants may carry off skulls and innominates from bone sites, or relocate them for some reason or another (possibly play or investigative behavior), while other elephants may prefer to carry or sort tusks, or ribs, or limb bones. Some elephants may carefully avoid stepping on bones, but others may not pay much attention. Some elephants may violently break robust limb elements by flinging them on the ground; others may only turn the elements gently or ignore them.

\section{Bones with 'Use-Wear'}

Very isolated traces of "wear" or edge-damage on broken bone fragments need not result exclusively from deliberate human use of the fragments as tools. Partly buried bones may be trampled, thus creating breaks or edge-damage only on the exposed parts (see Figure 5); sediment movement can create isolated wear on broken edges; carnivore gnawing may create isolated wear when broken edges are licked vigorously, rubbed against the ground, or worn against the carnivore's feet in an attempt to hold the bone steady while gnawing is going on. Before the wear traces on fossil specimens are attributed confidently only to human use of the bones, I would like to see more reliable and fair evaluations done of the bone-tool replicative studies. The studies that have been carried out are valuable in some ways, but the types of wear created during noncultural processes have not been examined with the same amount of energy and initiative. The wide range of possible causes for the wear traces should be very thoroughly studied, so the noncultural agencies can be eliminated.

\section{Bones with Multiple Generations of Modification}

At some sites, weathered or eroded bones are interpreted as raw materials from which tools were made (for example, the Hiscock site). These specimens thus are interpreted as showing multiple generations of modification: first came the weathering and the cracking or breaking that accompanied erosion of bones, followed by human actions to shape the bones, followed by human actions using the bones and thereby creating wear traces on the edges. Often, intricate engineering studies have been done, making the case for multiple generations and showing the plausibility of the scenarios. But the scenarios are often complex and the sequences of human actions seem to be embroidered to fit the modifications at hand. It is argued that the sequences of modifying actions were culturally directed, since natural processes could never have proceeded in such sequences, or that nonculturally modified bones could never have differentially worn or weathered parts. Yet bones in natural deposits go through many different generations of modifications, and different parts of the same elements may not be modified in the same ways. The null hypothesis that one expects to see addressed in these replicative or engineering studies - that the multiple generations of modification resulted from processes in nature over thousands of years- seems to be rejected not for a strong reason (by being shown impossible) but for a weak reason (by being argued as improbable).

\section{Season-of-Death Patterns}

Animals in nature die for many different reasons, and in all possible seasons. Simply because many mastodonts died in the autumn is not a strong argument that they were killed by humans stocking up on meat to use over the coming winter. The presence of ambiguous marks on the bone surfaces may make the case a little stronger that the mastodonts were indeed butchered by humans, but does not clinch the case. The scenario is made plausible, because it is understandable, but what is missing is: 1) stronger evidence that the season of death has been accurately interpreted (for example, maybe 


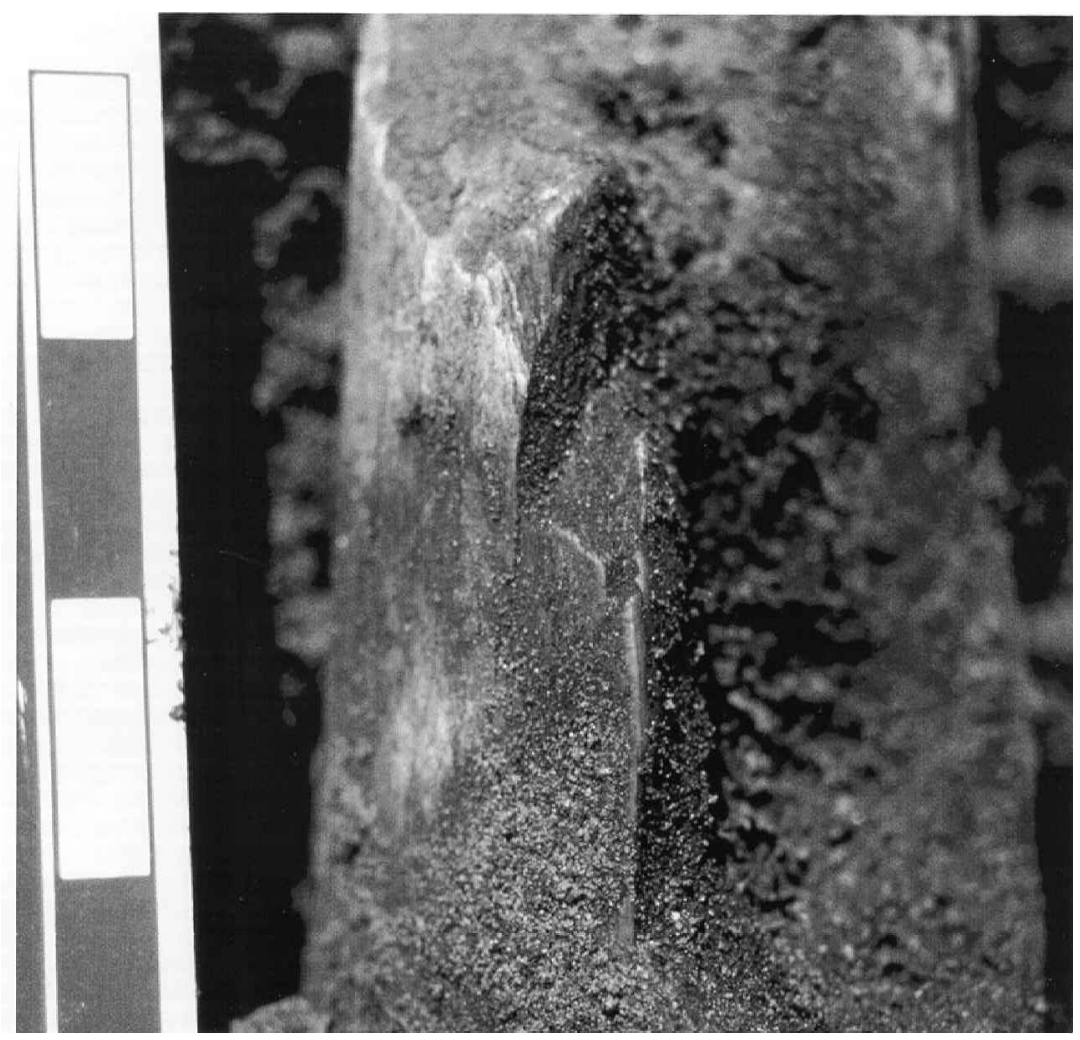

Figure 5 A partly buried, trample-broken elephant bone with abrasive smoothing and polish on part of the exposed fracture edge, created by trampling. The scale bar on the left is marked in inches. Photographed in Zimbabwe by G Haynes.

the strength of the evidence would be enhanced if the living elephants can be studied to determine microscopically if their hard tissue reflects seasonal changes in physiology and behavior in the same ways that the fossil tissues are interpreted to show), 2) unimpeachable evidence that the "butcher marks" on the bones were made by people sectioning the mastodont carcasses (see above), and 3 ) the sample can be expanded greatly with further study to see if similar patterning can be found in different proboscideans from different world areas and different time periods, when the human presence is not a possibility.

My quibbles here are with interpretations of sites from several time intervals in the Americas, including the terminal Pleistocene when human foragers are clearly present, and also earlier in the last Glacial phase, when questions still remain about the presence of people. It may seem unnecessarily contrary for me to argue about the possible meanings of bone modifications in assemblages such as those found at the Great Lakes mastodont sites (for example, Pleasant Lake), because the sites date to a time when human beings were indisputably present. Advocates of a very early, preClovis human presence in the Americas possibly would argue that the skeptical standards that once were applied by the so-called "Clovis police" (also known as the "Clovis mafia")—-self-appointed enforcers of the rules of interpretation who maintained the status quo by keeping Clovis the first people in the New World-are irrelevant, because Monte Verde has been universally accepted in all its interpretations. However, it should be argued in response that even if the Clovis-first enforcers 
have disbanded, the standards of archeological interpretation must not be relaxed. Unsound interpretations are bad, no matter how many archeologists they may please; sound ones are good, no matter how few they satisfy. The interpretations we argue about must remain open to question.

\section{Two Competing Paradigms that Drive the Debate}

The continuing debate about archeological standards is not a clash of personalities alone. I think it reflects two different ways of viewing archeological data, or two different "paradigms", as the word sometimes is used. One paradigm can be called the "Where's Waldo" view of bone sites, named after the famous series of children's cartoons and books (copyrighted, of course). In this paradigm, the analyst brings to the study an implicit view that clearly defined sets of modifications made by people can be spotted by first visually scanning bone assemblages that contain broken bones in suspicious proportions, then microscopically examining certain specimens whenever necessary to identify the features that are diagnostic of human actions. I see this paradigm as behind many interpretations of larger fossil bone assemblages. Careful examination of specimens-perhaps a sampling of the best-looking few out of thousands that may be available-inevitably results in the discovery of some that are thought to be artifacts and nothing but artifacts. My impression is that the "Where's Waldo" intellect believes that Waldo hides in the assemblages, and that every broken-bone site probably has at least one artifact hidden in it. One simply must look hard to find it. The paradigm does not encourage analysts to believe that in any bone assemblage a wide range of marks and modifications exists. Some of the marks and modifications may be perfect matches for true cutmarks or breaks made by people, no matter what the true causes were for the modifications. Some other modifications may be less than perfect matches for replicated cutmarks or breakage. Some modifications will be poor matches, and some will be very different. When an analyst tries to pick out only the perfect matches, that analyst has rejected the possibility that the modifications may have had multiple causes or that the causes could have been noncultural.

The other paradigm is one that may be called "Fill a room with chimpanzees and typewriters, and eventually...". This name is based on the old saying that if you were to give a mob of chimpanzees all the time in the world and plenty of keyboards, eventually they would produce the complete works of Shakespeare. It is possible that I myself go through life with this paradigm. My inclination is to believe that probably every broken-bone site has at least one artifact lookalike in it, and the larger the assemblage the better the chances are of finding false "artifacts."

Neither one of these paradigms is especially helpful in a science such as archeology, which depends so much on making persuasive interpretations of data, rather than on referring to clear and incontrovertible laws of factual meaning. The two viewpoints must meet in the middle of the archeological courtroom to argue about the evidence and the facts, and each must try to make a clearer and stronger case than the other. But in the end the jury still must decide the verdict about mastodont and mammoth sites based on opinion and plausibility rather than on proof.

\section{CONCLUSION}

Geologists and other earth scientists have thoughtfully embraced the Law of Uniformitarianism for nearly two centuries. Stratigraphers and sedimentary geologists know that in order to understand and explain the prehistoric processes of sedimentation, erosion, redeposition, and landscape evolution, they must observe and learn the processes that affect sediments and landscapes today. In other words, earth scientists gain a familiarity with the object of their interpretations - the earth's surface. Yet, the interpreters of fossil mammalian bones do not seem to have these sorts of opportunities to gain familiarity with modern bones entering modern sediments in modern landscapes. A relatively 
small number of actualistic studies have ever been carried out, and only a tiny proportion of them have been long-term and instructive beyond the anecdotal stage. While a fair number of scholars can describe a one-, two-, or three-year study of bones or of a few animal carcasses, or similar limited taphonomic projects, almost none devote a significant chunk of time—at least a decade, or better yet an entire career- to observing the variety and patterning of bone modifications in nature that would seem absolutely necessary for reliable interpretations of fossil bones whose potential "meanings" remain ambiguous.

Because it is almost inevitable that prehistorians are unaware of most of the noncultural bone-modifying, bone-depositing, bone-reworking processes in the world, due to the fact that they so rarely have a chance to see the ways in which natural agents affect mammalian bones, they are in effect poorly prepared to make informed arguments about fossil bone site evidence. Hence, plausible arguments about bone-modifications in prehistory are not necessarily unassailable arguments. If I were a prehistorian who believed that a particular fossil bone had been modified by human actions, and if I tried to make that case through a series of arguments that established its plausibility, I will have failed if I do not anticipate adversarial arguments based on knowledge of the few long-term actualistic studies, knowledge that may be perceived as esoteric or arcane by geochronologists lacking familiarity with the taphonomic literature.

One argument often advanced to deflect the kinds of cautionary evidence emerging from actualistic field studies, which I have described in this paper, is that the chance of noncultural processes creating patterned marks or breakage in proboscidean bone assemblages must be very low. There is more than one good reason to dispose of this "argument" quickly. Number one is that nature is not random-patterns and regularities exist in many processes that affect animal bones. Another reason may be called the "inevitability of the improbable" generalization. I will illustrate this argument from my own actualistic fieldwork.

Over the course of more than two decades, studying animal bones in natural settings, I have photographed, measured, mapped, and collected specimens from hundreds of death sites and carcasses of wild animals_-including elephants, bison, moose, African buffalo, deer, giraffe, and so on. Numerous examples have been documented of bone flaking, green-bone fragmentation, trample-marking that look like cutmarks, and other modifications in these noncultural assemblages. The marks, for the most part, occur in the midst of other modifications that bone analysts could probably tell were created by noncultural processes. They are present, in other words, in assemblages that provide unambiguous information about the natural origins of the modifications. But I have also noted examples of sites where a proportion of the bones had been modified-with surface marks or greenbone breakage - that analysts would not be able to distinguish from cultural modifications, and that do not occur in the midst of clear noncultural modifications.

To put these observations in context, I refer to one particular study area, a national park in Zimbabwe, about $14,600 \mathrm{~km}^{2}$ in size. Approximately 30,000 elephants use the park as their main range. Over the last two decades, I have examined over 700 dead elephants in the park, most of which had died of natural causes (drought, disease, intraspecific encounters, old age, etc.). At least five of the skeletons had bones modified in a manner that I am certain no analyst would be able to distinguish from the cultural creation of cutmarks or green-bone breakage. These five (and probably more) sites were deposited over a 17-yr timespan, making an input rate of about one per $3+\mathrm{yr}$. If I use this rate to predict input per century, I come up with 34 sites per $100 \mathrm{yr}$ that will contain elephant bones easily mistaken for the products of human actions. 
The United States is 665 times larger than my main study area in Africa. If the United States produced as many sites as does the African national park, it would see the creation of over 20,000 ambiguous sites every century, or a total of 200,000 every millennium. Of course, this figure is unlikely, because many bone sites do not preserve, due to erosion or bone weathering. But even if only $1 \%$ of this number ever gets preserved and fossilized, the total of expected ambiguous sites is 2000 per millennium, or two per year. When you look at the time spread of the mammoth and mastodont sites in this paper's selective sample — most of them dating from 18,000 to $10,000 \mathrm{BP}$ - a reasonable expectation would be that there should be at least 16,000 ambiguous sites in the United States from this interval of the late Pleistocene. If we are even more conservative and decide to reduce the percentage of such bone sites that may be predicted to fossilize and be well preserved, from $1 \%$ to an extremely stingy $0.1 \%$, we are still left with an expected number of 16 sites in the record that we may reasonably expect to provide data that can be interpreted in error.

If a number between 16,000 and 16 is a reasonable estimate, then any argument about the potential meaning of the North American fossil sites must be very persuasive indeed to win the case. So far, no such clinching arguments have appeared in the literature.

So what does all this have to do with dating the Americas and with the measurement of Time itself? A date on any randomly selected mastodont or mammoth bone tells us only that the animal lived at a certain time period. It tells us nothing clearly about the manner of the animal's death, the conditions of its life, or its behavior. Other kinds of evidence must be evaluated to inform us about those things. But a ${ }^{14} \mathrm{C}$ date run on a mastodont or mammoth bone that is putatively an artifact, argued to be modified by human actions, could tell us something far more profoundly important. If the dated bone specimen has been interpreted with vigorous and persuasive clarity, and is widely believed to be humanly modified, the radiocarbon dating itself has become a critical part in the story of human entry and establishment in the Americas. An early date would be the most significant contribution possible in the story. But if the specimen is ambiguous, and if it may not be an artifact after all, the dating is tainted evidence about the human story in the Americas, and while it may change the jury's ideas about the meaning of the archeological data, it is still part of a package of bad evidence. The dating is never irrelevant, but unless the sample is selected very carefully it may be unnecessary and misleading, and make the quest to find the Americas' first colonizers an exercise in bad judgement.

\section{ACKNOWLEDGMENTS}

The Zimbabwe Department of National Parks and Wild Life Management supported the actualistic studies discussed in this paper. Financial assistance has come from the National Geographic Society, the Leakey Foundation, and my own bank accounts. My wife Janis Klimowicz provided the most critical help and collegial advice, encouragement, and maintenance.

\section{REFERENCES}

Anderson AD, editor. 1975. The Cooperton mammoth: an Early Man bone quarry. Great Plains Journal 14(2):130-72.

Cotterell B, Kamminga J. 1990. The mechanics of pre-industrial technology. Cambridge: Cambridge University Press.

Dillehay T D. 1997. Monte Verde: a Late Pleistocene settlement in Chile. Volume 2: The Archaeological Context and Interpretation. Washington DC: Smithsonian Institution Press.

Dunnell RC, Hamilton TM. 1995. Age of the Miami Mastodon. Current Research in the Pleistocene 12: 91-2.

Fagan BM. 1995. Ancient North America: the archaeology of a continent. 2nd edition. New York: Thames and Hudson.

Fisher DC. 1984. Mastodon butchery by North American Paleo-Indians. Nature 308:271-2.

Fisher DC. 1987. Mastodont procurement by Paleoindians in the Great Lakes Region: hunting or scavenging? In: Nitecki MH, Nitecki DV, editors. Evolution of human hunting. New York: Plenum Press. p 309-421. 
Fisher DC. 1996. Extinction of proboscideans in North America. In: Shoshani J, Tassy P, editors. The proboscidea: evolution and palaeoecology of elephants and their relatives. Oxford: Oxford University Press. $\mathrm{p}$ 296-315.

Frison GC, Todd LC. 1986. The Colby Mammoth site: taphonomy and archaeology of a Clovis kill in Northern Wyoming. Albuquerque: University of New Mexico Press

Hall DA. 1997. Nebraska follow-up: flaked bone suggests Americans used mammoths as tool materials. Mammoth Trumpet 12(3):7-8.

Hamilton TM. 1996. The Miami mastodon, 23SA212. The Missouri Archaeologist 54:79-88.

Hannus LA. 1990. The Lange-Ferguson site: a case for mammoth bone-butchering tools. In: Agenbroad L, Mead J, Nelson L, editors. Megafauna and man: discovery of America's heartland. Mammoth site of Hot Springs, South Dakota, Scientific Papers, Volume 1. p 86-99.

Haynes G. 1991. Mammoths, mastodonts, and elephants: biology, behavior, and the fossil record. Cambridge: Cambridge University Press.

Irving WN, Jopling AV, Klitsch-Armstrong I. 1989. Studies of bone technology and taphonomy, Old Crow Basin, Yukon Territory. In: Bonnichsen R, Sorg M, editors. Bone modifications. Orono, Maine: Center for the Study of the First Americans. p 347-79.

Johnson, E, editor. 1987. Lubbock Lake: Late Quaternary studies on the Southern High Plains. College Station, Texas: Texas A\&M University Press.

Laub RS. 1990. The Hiscock site (western New York): recent developments of Pleistocene and Early Holocene Interest. Current Research in the Pleistocene 7: $116-8$.

Laub RS. 1995. The Hiscock site (western New York): recent developments in the study of the Late-Pleistocene Component. Current Research in the Pleistocene $12: 26-9$

Laub RS, Haynes G. 1998. Fluted points, mastodons, and evidence of Late-Pleistocene drought at the Hiscock site, western New York State. Current Research in the Pleistocene 15:32-4.

Mandryk CAS. 1998. A geoarchaeological interpretation of the Lamb Spring site, Colorado. Geoarchaeology 13(8):819-46.

Mandryk CAS. 1999. Geoarchaeological analysis and interpretation of the Lamb Spring site, Colorado. Paper presented at the 64th Annual Meeting of the Society for American Archaeology, Seattle, Washington, 2428 March 1999.

Mehl M. 1967. The Grundel Mastodon. Missouri Geological Survey and Water Resources Report of Investigations. Number 35.

Meltzer DJ. 1993. Search for the first Americans. Wash- ington DC: Smithsonian Books.

Meltzer D, Grayson D, Ardila G, Barker A, Dincauze D, Haynes CV, Mena F, Nunez L, Stanford D. 1997. On the Pleistocene antiquity of Monte Verde, Southern Chile. American Antiquity 62(4):659-63.

Miller SJ. 1989. Characteristics of mammoth bone reduction at Owl Cave, the Wasden site, Idaho. In: Bonnichsen R, Sorg M, editors. Bone modifications. Orono, Maine: Center for the Study of the First Americans. p 381-93.

Miller SJ, Dort W, Jr. 1978. Early man at Owl Cave: current investigations at the Wasden site, Eastern Snake River Plain, Idaho. In: Bryan AL, editor. Early Man in America from a Circum-Pacific Perspective. University of Alberta Department of Anthropology Occasional Paper Nr 1. p 129-39.

Morlan RE. 1980. Taphonomy and archaeology in the Upper Pleistocene of the Northern Yukon Territory. Archaeological Survey of Canada. Paper Nr 94.

Morlan RE. 1986. Pleistocene archaeology in Old Crow Basin: a critical appraisal. In: Bryan AL, editor. New evidence for the Pleistocene peopling of the Americas. Orono, Maine: Center for the Study of Early Man. p 27-48.

Overstreet DF, Stafford TW Jr. 1997. Additions to a revised chronology for cultural and non-cultural mammoth and mastodon fossils in the southwestern Lake Michigan Basin. Current Research in the Pleistocene 14:70-1.

Overstreet DF, Joyce DJ, Hallin K, Wasion D. 1993. Cultural contexts of mammoth and mastodon in the Southwest Lake Michigan Basin. Current Research in the Pleistocene 10:75-7.

Rancier J, Haynes G, Stanford D. 1982. 1981 Investigations at Lamb Spring. Southwestern Lore 8(2):1-17.

Stanford D. 1979. The Selby and Dutton sites: evidence for a possible pre-clovis occupation in the High Plains. In: Humphrey R, Stanford D, editors. Pre-Llano cultures of the Americas. Washington, DC: Anthropological Society of Washington. p 101-23.

Stanford D, Bonnichsen R, Morlan RE. 1981a. The Ginsberg experiment: modern and prehistoric evidence of a bone flaking technology. Science 212:438-40.

Stanford D, Wedel WR, Scott GR. 1981b. Archaeological investigations of the Lamb Spring site. Southwestern Lore 47(1):14-27.

Steele DG, Carlson DL. 1989. Excavation and taphonomy of mammoth remains from the Duewall-Newberry site, Brazos County, Texas. In: Bonnichsen R, Sorg M, editors. Bone modifications. Orono, Maine: Center for the Study of the First Americans. p 413-30.

Tomenchuk J, Laub RS. 1995. New insights into LatePleistocene bone technology at the Hiscock site, Western New York State. Current Research in the Pleistocene 12:71-4. 